\title{
Population Dynamics of Nassarius reticulatus (Gastropoda, Prosobranchia) in Gullmar Fjord, Sweden
}

\author{
B. Tallmark \\ Department of Zoology, Uppsala University, Box 561, S-75122 Uppsala, Sweden
}

\begin{abstract}
The population dynamics of Nassarius reticulatus (L.) (Gastropoda, Prosobranchia) was investigated in Gullmar Fjord on the Swedish west coast from 1973 to 1979. A fairly well-defined population on a shallow, sandy bottom in Kvarnbukten Bay $\left(36000 \mathrm{~m}^{2}\right)$ was intensively studied. Settling of veliger larvae was very irregular and normally only took place where the organic content of the substrate was fairly high, i. e. in deeper water. The snails, especially small ones ( $\leqslant 15 \mathrm{~mm})$, were greatly attracted to detritus-rich substrates, whereas larger ones congregated on carrion. The snails in Kvarnbukten Bay spent their first 3 years in the settling area living mainly on detritus. The change in diet may be a factor influencing the intraspecific competition between small and large snails. When nearly 4 years old (ca. $15 \mathrm{~mm}$ ) they become sexually mature. From then on most of them participated in the yearly migrations: in April and May from winter quarters in deeper water (1-5 $\mathrm{m}$ depth) to the shallow part of the bay $(0-1 \mathrm{~m})$ where they spent the summer, and then back again in September to December. Growth rate was fast during the first 3 years with a length increment of about $5.5 \mathrm{~mm} \mathrm{year}^{-1}$, but then decreased considerably, also becoming individually very variable. Maximum age was about 15 years. Fecundity was high: ca. 6000 eggs female ${ }^{-1}$ year $^{-1}$; females spawned every year. Mortality rate during the planktonic phase was high but there were few predators on larger snails, parasitism in shallow water probably being the most important cause of losses at this age. Temperature was one of the main proximate factors affecting locomotory activity, migration, spawning and growth. Threshold temperatures for various activities were narrowly defined. Irregular settling of larvae and hence sporadic recruitment to the shallow parts of the bays seemed to be the main reason for population fluctuations in different bays. Advantages of inshore migration (temperature and availability of food) seemed to balance disadvantages (mainly parasitism) and this may explain the dimorphism in migratory habits. As a whole these snails show several special adaptations to the varying environment in this non-tidal, soft bottom littoral.
\end{abstract}

\section{INTRODUCTION}

The netted dog whelk Nassarius reticulatus (L.) is abundant on shallow sandy bottoms and in rock pools with gravel along the European coasts. Several studies have been devoted to various aspects of its ecology, such as larval development (Ankel, 1929; Lebour, 1931; Pilkington and Fretter, 1970; Fretter and Shale, 1973), chemical sense (Henschel, 1933; Crisp, 1971; Crisp et al., 1978), feeding (Crisp, 1978), reaction to heated water effluents (Barnett, 1972) and general biology (Rasmussen, 1973). The allopatric American species, $N$. obsoletus (Say), has also been the subject of several investigations, such as on reproduction (Scheltema, 1961, 1965, 1967), chemoreception (Copeland, 1918; Carr 1967a, b) and general ecology (Dimon, 1905; Batchelder, 1915; Stephens et al., 1953; Jenner, 1956, 1958, 1959; Scheltema, 1964; Crisp, 1969; Sastry, 1970; Dippolito et al., 1975).
Within the frame of a broad study of the animal community in a shallow sandy bay in Gullmar Fjord on the Swedish west coast the ecology of Nassarius reticulatus has been examined previously from various perspectives (Eriksson and Tallmark, 1974; Eriksson et al., 1975a, b; Tallmark and Norrgren, 1976). The study area, Kvarnbukten Bay, harbours a relatively welldefined population of $N$. reticulatus. In comparison with most sites where sandy bottom communities have been studied, Kvarnbukten Bay differs sharply in virtually lacking tidal effects. The present paper attempts a synthetic view of the population dynamics of $N$. reticulatus in the study area. Questions asked include: (a) What factors regulate the seasonal migrations of the snails? (b) What factors affect their spatial distribution during summer? (c) What do the snails eat? (d) What mechanism regulate the growth rate and how old can the snails become? (e) How do recruitment and mortality affect the population and what factors influence 
these parameters? (f) What is the reason for the annual fluctuations in immigration of snals to the benthic population in shallow water in Kvarnbukten Bay? $(\mathrm{g})$ Does the snail population in Kvarnbukten Bay differ from neighbouring populations and if so, in what respects?

\section{MATERIAL AND METHODS}

The main investigation area, Kvarnbukten Bay (Lat. $58^{\circ} 15^{\prime} \mathrm{N}$, Long. $11^{\circ} 28^{\prime} \mathrm{E}$ ), covers ca. $36000 \mathrm{~m}^{2}$ between HWL (high water level) and the depth of $1 \mathrm{~m}$, as described earlier (Evans and Tallmark, 1975, 1976). Outside this depth line the slope towards deeper water is steeper. The bay is surrounded by rocky shores and can be described as an isolated pocket beach (Fig. 1). The substrate is about $80 \%$ fine and very fine sand (Wentworth scale). In certain parts the sand is intermingled with gravel and shells, in other the bottom is covered with eel-grass Zostera marina (L.) or consists of banks of Mytilus edulis L.; in both cases with a relatively high content of organic matter. On the basis of water depth and organic content of the substrate the bay was divided into 10 strata. Mainly the same strata were used as those in previous studies of bivalve molluscs and polychaetes (Evans and Tallmark, 1976. 1977; Evans et al., unpublished). In addition, samples were taken in 2 strata in deeper water (G1, G2).
Random samples were taken in each stratum. Sample size was $1 \mathrm{~m}^{2}$; samples were never taken less than $4 \mathrm{~m}$ from each other on any one particular occasion to avoid disturbance. A $1 \times 1 \mathrm{~m}$ frame was placed on the bottom, and the substrate inside the frame was dug up to a depth of ca. $5 \mathrm{~cm}$ with a strengthened finemeshed bag net. The material was sieved through a $2 \mathrm{~mm}$ mesh net. Nassarius reticulatus (L.) were counted, their length measured with an accuracy of $0.1 \mathrm{~mm}$ and, since autumn 1975, the growth (see below) achieved during the previous year was measured; 80 to 100 samples were taken almost every month from February 1974 to August 1976 and subsequently about every third month until November 1979.

For comparison, abundance, size frequency distribution and individual growth in other Nassarius reticulatus populations were controlled every spring and autumn in deeper water just outside the investigation area proper and in the fishing harbour at Lysekil, hereafter called Lysekil harbour, $3 \mathrm{~km}$ NW of Kvarnbukten Bay using a Petersen grab and an Ockelmann sledge. $N$. reticulatus displays more or less distinct year rings, and this together with the thickness of the outer lip of the shell allowed the growth of the previous year to be measured. Furthermore, 1000 snails in 1973 and 2800 in 1974 were individually marked with fishtags $(10 \times 3 \mathrm{~mm})$, released and recaptured in the monthly sampling program to check their growth and home fidelity through the years.

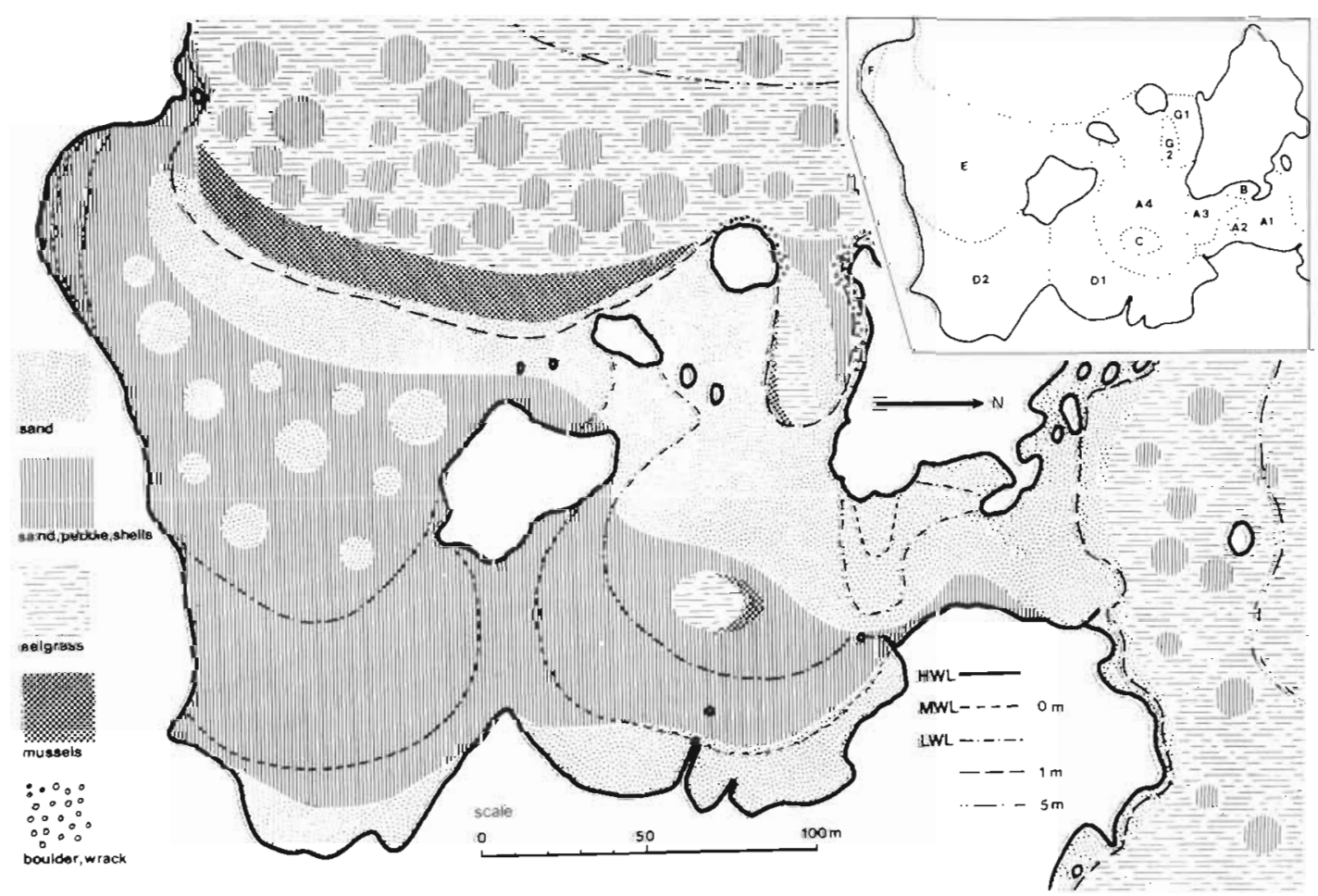

Fig. 1. Map of Kvarnbukten Bay. HWL: high-water level ( $\approx 0.25 \mathrm{~m}$ above MWL); MWL: mean-water level; LWL: Low-water level $(\approx 025 \mathrm{~m}$ below $\mathrm{MWL})$. Inset: stratification for sampling purposes 
The monthly mean values of the surface water temperature in Kvarnbukten Bay were calculated on the basis of records from a Grant thermograph for most of the period 1974-1978. Supplementary observations of the activities of the snails in the field were collected at frequent intervals, at least every 2 weeks.

Survival and growth as functions of the amount of food available were studied in the laboratory from April to October 1975, at the same temperatures as in the bay $\left( \pm 1 \mathrm{C}^{\circ}\right)$. About 200 snails were kept on a substrate of incinerated sand without organic matter. One half of these was starved, the other half given $0.004 \mathrm{~g}$ mussel flesh (dry weight) animal $\mathrm{l}^{-1} \mathrm{~d}^{-1}$. Another 200 snails were kept in sand from the bay (approx. $0.5 \%$ dry weight organic matter), half of them being starved, the other half fed as above. Both types of substrate were renewed once a week.

The fecundity of Nassarius reticulatus was measured by collecting egg capsules in the field and counting the average number of eggs per capsule, and by isolating pairs of snails in aquaria to ascertain the number of capsules per female. The time for hatching and larval settlement at different temperatures was determined by keeping egg capsules and larvae in recirculating aquaria over a fine mesh net $(0.2 \mathrm{~mm})$ and feeding the larvae with phytoplankton (Cricosphaera spp.).

\section{RESULTS}

\section{Migrations}

The snails migrated from the shallower areas in autumn and aggregated in large numbers just outside the investigation area $(1-5 \mathrm{~m}$ depth), particularly in patches of eel-grass, e. g. in Stratum G2 and north of the study area (Fig. 1). There they remained immobile during the winter at water temperatures below ca. $4^{\circ} \mathrm{C}$. When the water temperature rose above $5^{\circ} \mathrm{C}$ in spring they resumed activity but the migration into the shallow bay did not start until the water temperature rose above $7^{\circ} \mathrm{C}$ (April). The inshore migration was completed in June. From June to August the snails were fairly stationary but then their mobility increased. Initially they moved at random and achieved maximum dispersion in September when the water level allowed them to reach the shallowest areas. Subsequently the migration outwards started and continued until December. The general migration pattern is shown in Figure 2.

Most of the snails migrated to the area just north of the study area. Recaptures of marked snails showed that there was no homing tendency. Thus, for example, snails immigrating from the west in the spring might emigrate to the north in the autumn and vice versa.
Many of the larger snails ( $>23 \mathrm{~mm}$ ) in Stratum $\mathrm{C}$ were resident throughout the year and were recaptured at the same place year after year. Trematode infections in large snails resulted in lowered locomotory activity (Tallmark and Norgren, 1976).

About half of the snails remaining in the shallow area during winter inhabited the eel-grass patch, in Stratum C (Fig. 1).

\section{Spatial Dispersion}

The mean number of snails varied greatly even between adjacent strata (Table 1, see also Figs 1 and 2). The low abundance in the southern part of the bay (Strata D 2, E and F) was probably in part due to the long distance to the main settling and winter area north and north-west of the bay. There is a much gentler slope to deeper water in the southwestern part which forced the snails to undertake much longer migration between their winter and summer quarters. During spring and summer the southern part was isolated most of the time by a sand barrier which prevented immigration. There was no recruitment in
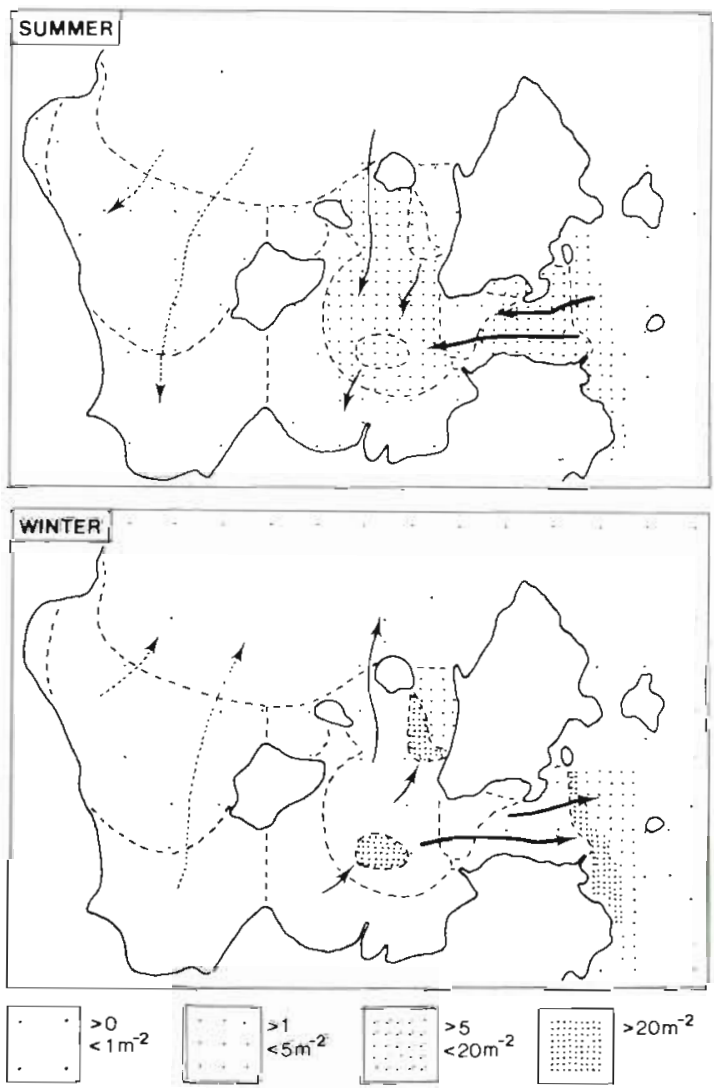

Fig. 2. Nassarius reticulatus. Schematic migration pattern and population density (inds $\mathrm{m}^{-2}$ ) in different parts of Kvarnbukten Bay. Breadth of arrows indicate magnitude of migrations 
Table 1 Nassarius reticulatus. Average density (inds $\mathrm{m}^{-2}$ ) and S.D. in different strata in Kvambukten Bay (1974-1979). Stratification, see Figure 1. Note differences in area during different years in Strata A1 and A2. Number of samples (1 m²): A1 6-13, A2 2-4, A3 3-6, A4 11-17, B 2-5, C 3-5, D1 6-12, D2 6-12, E 9-16, G1 5-9, G2 6-11

\begin{tabular}{|c|c|c|c|c|c|c|c|c|c|c|c|c|}
\hline 1974 & $\begin{array}{c}\text { A1 } \\
2000 \mathrm{~m}^{2}\end{array}$ & $\begin{array}{c}\text { A2 } \\
200 \mathrm{~m}^{2}\end{array}$ & $\begin{array}{c}\text { A3 } \\
900 \mathrm{~m}^{2}\end{array}$ & $\begin{array}{c}\text { A4 } \\
5900 \mathrm{~m}^{2}\end{array}$ & $\begin{array}{c}\text { B } \\
250 \mathrm{~m}^{2}\end{array}$ & $\begin{array}{c}\text { C } \\
500 \mathrm{~m}^{2}\end{array}$ & $\begin{array}{c}\mathrm{D} 1 \\
7200 \mathrm{~m}^{2}\end{array}$ & $\begin{array}{c}\text { D2 } \\
6500 \mathrm{~m}^{2}\end{array}$ & $\begin{array}{c}\mathbf{E} \\
10700 \mathrm{~m}^{2}\end{array}$ & $\begin{array}{c}\mathbf{F} \\
600 \mathrm{~m}^{2}\end{array}$ & $\begin{array}{c}\mathrm{G} 1 \\
750 \mathrm{~m}^{2}\end{array}$ & $\begin{array}{c}\mathrm{G} 2 \\
450 \mathrm{~m}^{2}\end{array}$ \\
\hline Feb. & $3.2 \pm 3.6$ & 0 & 0 & $1.2 \pm 2.2$ & 4.5 & 37.5 & 0 & 0 & $0.2 \pm 0.4$ & 0 & 3.1 & 53.1 \\
\hline April & $11.0 \pm 9.6$ & 0 & 0 & $6.0 \pm 6.1$ & 6.5 & 41.0 & 0 & 0 & $0.9 \pm 0.8$ & 0 & 11.3 & 57.0 \\
\hline May & $27.8 \pm 15.3$ & 82.0 & 1.0 & $10.7 \pm 6.0$ & 8.5 & 43.0 & 0 & 0 & $1.1 \pm 0.9$ & 0 & 8.1 & 27.1 \\
\hline June & $21.2 \pm 7.0$ & 80.0 & 2.3 & $11.8 \pm 6.0$ & 12.5 & 43.3 & $0.9 \pm 1.3$ & 0 & $0.8 \pm 0.7$ & 0 & 9.0 & 41.8 \\
\hline Aug. & $17.1 \pm 7.3$ & 76.5 & 4.3 & $10.5 \pm 6.0$ & 12.0 & 36.0 & $1.9 \pm 1.4$ & 0 & $0.8 \pm 0.6$ & 0 & 6.5 & 26.1 \\
\hline Sept. & $7.7 \pm 3.2$ & 51.7 & 5.3 & $10.3 \pm 6.2$ & 13.5 & 37.2 & $4.0 \pm 2.1$ & & & & 6.0 & 32.7 \\
\hline Oct. & $13.9 \pm 7.6$ & 61.3 & 2.4 & $5.1 \pm 3.6$ & 12.5 & 53.3 & $0.5 \pm 0.7$ & & & & 17.4 & 46.5 \\
\hline Nov. & $8.7 \pm 9.0$ & 0 & 0.2 & $3.4 \pm 2.7$ & 17.7 & 62.7 & 0 & 0 & $0.1 \pm 0.3$ & 0 & 26.2 & 48.5 \\
\hline 1975 & $2100 \mathrm{~m}^{2}$ & $100 \mathrm{~m}^{2}$ & & & & & & & & & & \\
\hline Jan. & $5.3 \pm 5.7$ & 0 & 0 & $0.4 \pm 0.5$ & 2.5 & 69.0 & 0 & & & & 13.4 & 59.1 \\
\hline Feb. & $4.3 \pm 6.6$ & 0 & 0 & $2.2 \pm 2.2$ & 4.0 & 54.3 & 0 & 0 & 0 & 0 & 6.4 & 71.8 \\
\hline March & $5.3 \pm 7.7$ & 0 & 0 & $1.9 \pm 2.0$ & 4.0 & 51.3 & 0 & & & & 17.7 & 60.1 \\
\hline April & $4.3 \pm 4.0$ & 0 & 0 & $1.9 \pm 1.7$ & 5.0 & 52.6 & 0 & & & & 16.5 & 55.3 \\
\hline May & $12.5 \pm 7.0$ & 19.5 & 4.0 & $4.2 \pm 3.0$ & 11.0 & 21.0 & 0 & 0 & $1.3 \pm 1.1$ & 0 & 13.4 & 41.6 \\
\hline June & $15.4 \pm 6.8$ & 34.5 & 3.8 & $7.2 \pm 3.2$ & 11.0 & 21.7 & $0.8 \pm 0.7$ & & & & 4.2 & 32.8 \\
\hline July & $11.5 \pm 4.5$ & 40.0 & 6.3 & $6.7 \pm 4.2$ & 11.7 & 34.8 & $2.0 \pm 1.8$ & & & & 5.0 & 32.7 \\
\hline Aug. & $13.5 \pm 6.4$ & 42.0 & 5.7 & $5.5 \pm 3.1$ & 16.8 & 37.4 & $2.6 \pm 2.6$ & 0.6 & $0.8 \pm 1.0$ & 0.3 & 6.0 & 30.8 \\
\hline Sept. & $10.3 \pm 3.2$ & 42.5 & 4.5 & $4.5 \pm 2.2$ & 10.0 & 37.0 & $3.9 \pm 2.2$ & & & & 12.0 & 27.5 \\
\hline Oct. & $10.6 \pm 3.7$ & 26.7 & 3.0 & $3.8 \pm 2.7$ & 13.3 & 40.8 & $0.3 \pm 0.5$ & & & & 11.5 & 41.0 \\
\hline Nov. & $10.7 \pm 3.8$ & 23.0 & 0.8 & $2.3 \pm 1.9$ & 13.3 & 30.8 & 0 & 0 & $0.2 \pm 0.4$ & 0 & 8.5 & 46.7 \\
\hline Dec. & $8.1 \pm 5.2$ & 17.3 & 0.5 & $1.3 \pm 1.3$ & 10.3 & 33.5 & 0 & & & & 8.2 & 33.5 \\
\hline 1976 & $2150 \mathrm{~m}^{2}$ & $50 \mathrm{~m}^{2}$ & & & & & & & & & & \\
\hline Jan. & $6.1 \pm 3.4$ & 6.7 & 0.3 & $0.8 \pm 1.0$ & 8.5 & 28.3 & 0 & & & & 6.2 & 32.0 \\
\hline Feb. & $6.8 \pm 3.7$ & 12.5 & 0.5 & $0.5 \pm 0.7$ & 12.0 & 27.5 & 0 & 0 & $0.2 \pm 0.4$ & 0 & 1.3 & 38.3 \\
\hline March & $6.5 \pm 5.6$ & 4.3 & 0.5 & $0.5 \pm 0.8$ & 8.0 & 27.0 & 0 & & & & 0.8 & 79.0 \\
\hline April & $7.3 \pm 4.0$ & 2.3 & 0 & $0.5 \pm 0.7$ & 3.0 & 21.0 & 0 & & & & 5.3 & 45.0 \\
\hline May & $7.8 \pm 4.7$ & 11.5 & 3.0 & $2.8 \pm 2.3$ & 9.1 & 13.0 & $0.4 \pm 0.7$ & 0 & $0.8 \pm 0.6$ & 0 & 3.0 & 18.5 \\
\hline June & $6.0 \pm 2.9$ & 27.0 & 3.8 & $4.5 \pm 2.4$ & 7.3 & 18.5 & $1.3 \pm 1.0$ & & & & 2.5 & 12.0 \\
\hline July & $10.1 \pm 4.4$ & 17.3 & 1.8 & $4.3 \pm 1.4$ & 5.7 & 28.5 & $1.3 \pm 0.9$ & & & & 2.0 & 22.8 \\
\hline Aug. & $5.2 \pm 2.2$ & 14.0 & 1.6 & $4.7 \pm 3.6$ & 1.3 & 29.5 & $1.7 \pm 1.2$ & 0.8 & $0.6 \pm 0.7$ & 0.2 & 2.3 & 21.5 \\
\hline Nov. & $3.4 \pm 2.2$ & 0.7 & 0 & $0.6 \pm 0.8$ & 0.8 & 18.3 & 0 & 0 & $0.1 \pm 0.4$ & 0 & 1.5 & 22.5 \\
\hline 1977 & $2200 \mathrm{~m}^{2}$ & $0 \mathrm{~m}^{2}$ & & & & & & & & & & \\
\hline Feb. & $1.6 \pm 2.8$ & & 0 & $0.1 \pm 0.4$ & 0 & 17.3 & 0 & 0 & $0.1 \pm 0.2$ & 0 & 3.2 & 20.8 \\
\hline May & $5.4 \pm 4.9$ & & 0 & $1.9 \pm 1.5$ & 0.5 & 14.5 & 0 & 0 & $0.3 \pm 0.5$ & 0 & & \\
\hline June & $3.8 \pm 1.9$ & & 1.6 & $2.2 \pm 1.5$ & 0.5 & 10.8 & $0.3 \pm 0.5$ & 0.2 & $0.4 \pm 0.7$ & 0.2 & 1.7 & 19.7 \\
\hline Aug. & $2.5 \pm 1.5$ & & 2.2 & $1.4 \pm 0.8$ & 6.5 & 9.5 & $1.0 \pm 0.8$ & 0.2 & $0.2 \pm 0.4$ & 0.2 & 0.5 & 9.0 \\
\hline Nov. & $4.8 \pm 3.8$ & & 0.4 & $0.6 \pm 0.8$ & 0.5 & 12.5 & 0 & 0 & $0.2 \pm 0.4$ & 0 & 2.7 & 18.0 \\
\hline \multicolumn{13}{|l|}{1978} \\
\hline Feb. & $0.6 \pm 0.8$ & & 0 & $0.3 \pm 0.5$ & 0 & 7.0 & 0 & 0 & $0.1 \pm 0.3$ & 0 & 6.7 & 77.8 \\
\hline May & $11.0 \pm 8.4$ & & 2.4 & $4.1 \pm 2.1$ & 0.5 & 19.0 & $0.3 \pm 0.5$ & 0 & $0.5 \pm 0.5$ & 0.2 & 2.0 & 21.3 \\
\hline Aug. & $7.6 \pm 2.8$ & & 4.0 & $6.6 \pm 4.0$ & 1.5 & 22.8 & $0.7 \pm 0.7$ & 0.3 & $0.7 \pm 0.6$ & 0.2 & 3.8 & 30.2 \\
\hline Nov. & $2.9 \pm 2.3$ & & 1.0 & $1.9 \pm 2.0$ & 2.0 & 28.5 & 0 & 0 & $0.2 \pm 0.4$ & 0 & & \\
\hline 1979 & $2300 \mathrm{~m}^{2}$ & & & & & & & & & & & \\
\hline March & $0.3 \pm 0.5$ & & 0 & $0.2 \pm 0.4$ & 0 & 18.5 & 0 & 0 & $0.1 \pm 0.3$ & 0 & 8.0 & 44.8 \\
\hline May & $1.1 \pm 2.1$ & & 0 & 0 & 0 & 13.8 & 0 & 0 & 0 & 0 & 10.8 & 33.2 \\
\hline June & $4.9 \pm 2.0$ & & 1.4 & $2.8 \pm 1.5$ & 1.3 & 16.0 & $0.8 \pm 0.9$ & 0 & $0.3 \pm 0.4$ & 0 & 3.5 & 27.2 \\
\hline Aug. & $11.1 \pm 6.8$ & & 2.2 & $2.8 \pm 1.8$ & 1.3 & 17.8 & $0.4 \pm 0.7$ & 0 & $0.3 \pm 0.5$ & 0 & 6.7 & 36.2 \\
\hline Nov. & 0 & & 0 & $0.1 \pm 0.3$ & 0 & 20.5 & 0 & 0 & 0 & 0 & & \\
\hline
\end{tabular}

Strata D 2, E and F from 1971 to 1977 and $75 \%$ of the snails were larger than $23 \mathrm{~mm}$. The water level apparently reduced the abundance of snails in Strata $A$ 3, D and $F$ which were periodically drained in spring and early summer (Evans and Tallmark, 1975).

The annual population fluctuations among larger snails ( $>18 \mathrm{~mm}$ ) just outside the bay were parallel to those of the summer population within the investigation area (Table 2, see also Table 1). This indicates that approximately the same proportion of the total population migrates into shallow water each year, but many snails remain in deeper water throughout the year (Table 2).

There was a strong positive correlation between the 
Table 2. Nassarius reticulatus. Density (inds $\mathrm{m}^{-2}$ ) in deeper water outside Kvarnbukten Bay. Numbers in brackets: snails $<18 \mathrm{~mm}$

\begin{tabular}{|c|c|c|c|c|c|c|}
\hline \multirow[b]{2}{*}{$\begin{array}{c}\text { Depth } \\
\mathrm{n} \times\left(\mathrm{m}^{2}\right)\end{array}$} & \multicolumn{2}{|c|}{ Southwest } & \multicolumn{2}{|c|}{ Northwest } & \multicolumn{2}{|c|}{ North } \\
\hline & $\begin{array}{c}2 \mathrm{~m} \\
10 \times 1\end{array}$ & $\begin{array}{c}5 \mathrm{~m} \\
20 \times 0.1\end{array}$ & $\begin{array}{c}5 \mathrm{~m} \\
20 \times 0.1\end{array}$ & $\begin{array}{c}10 \mathrm{~m} \\
20 \times 0.1\end{array}$ & $\begin{array}{c}2 \mathrm{~m} \\
10 \times 1\end{array}$ & $\begin{array}{c}5 \mathrm{~m} \\
20 \times 0.1\end{array}$ \\
\hline Sept. 1973 & 0.2 & 0 & $6.0(3.0)$ & 1.0 & $34.0(15.0)$ & $11.0(7.0)$ \\
\hline Oct. 1975 & 0.1 & 0.1 & $3.0(1.0)$ & 0 & $28.0 \quad(9.0)$ & $8.5(4.0)$ \\
\hline July 1977 & 0.1 & 0 & $1.5(1.0)$ & 0.1 & $10.0 \quad(7.0)$ & $3.0(2.0)$ \\
\hline Oct. 1977 & $0.2(0.1)$ & 0 & $3.0(2.0)$ & 0.3 & $21.0(10.0)$ & $5.5(3.5)$ \\
\hline Sept. 1979 & 0.1 & 0 & $3.0(2.0)$ & 0.1 & $17.0 \quad(8.0)$ & $4.5(3.5)$ \\
\hline
\end{tabular}

population density of Nassarius reticulatus and the organic content of the substrate. Especially the patches of eel-grass and the mussel banks acted as traps for detritus and were very attractive to the snails. In these strata ( $C$ and $G 2$ ) the mean numbers of snails were about 10 times higher than in adjacent strata with pure sand (A 4 and $G 1$, respectively). The same held for Stratum A 2 with a population of old, dying cockles Cardium edule (L.) between 1974 and 1976 (Evans, 1977), compared with Stratum A 1. The dispersion on pure sand was less patchy than on detritus-rich sand where the snails were more aggregated.

\section{Total Abundance}

The total number of Nassarius reticulatus in the study area was calculated by multiplying the mean values for each stratum with stratum area and summing these values (Fig. 3). Standard error was calculated by the formula on p. 521 in Snedecor and Coch- ran (1967). In 1974 the mean number of snails was $(4.8$ inds $\left.\mathrm{m}^{-2}\right)$ and then a decline until $1977\left(1.0 \mathrm{~m}^{-2}\right)$, while numbers rose again in 1978. These fluctuations were due to different rates of recruitment (see below). In 1977 when the mean density of $N$. reticulatus in Kvarnbukten Bay was lowest $\left(1.0 \mathrm{~m}^{-2}\right)$, populations in two adjacent bays with more organic matter in the bottom substrate (about $10 \%$ ) had corresponding values of 18.0 and $16.0 \mathrm{~m}^{-2}$ (Magnhagen, unpublished).

\section{Food Preferences in Relation to Snail Size}

Snails were more abundant in areas with a relatively high amount of available food, such as detritus in Strata C and G 2 and carrion in Stratum A 2, than in surrounding areas with pure sand (Table. 1). Different size classes clearly preferred different kinds of food. Thus the smaller snails gathered more in $\mathrm{C}$ with a relatively high content of organic matter (Table 3), as well as in Stratum G 2, than in A 4 and G 1, respec-

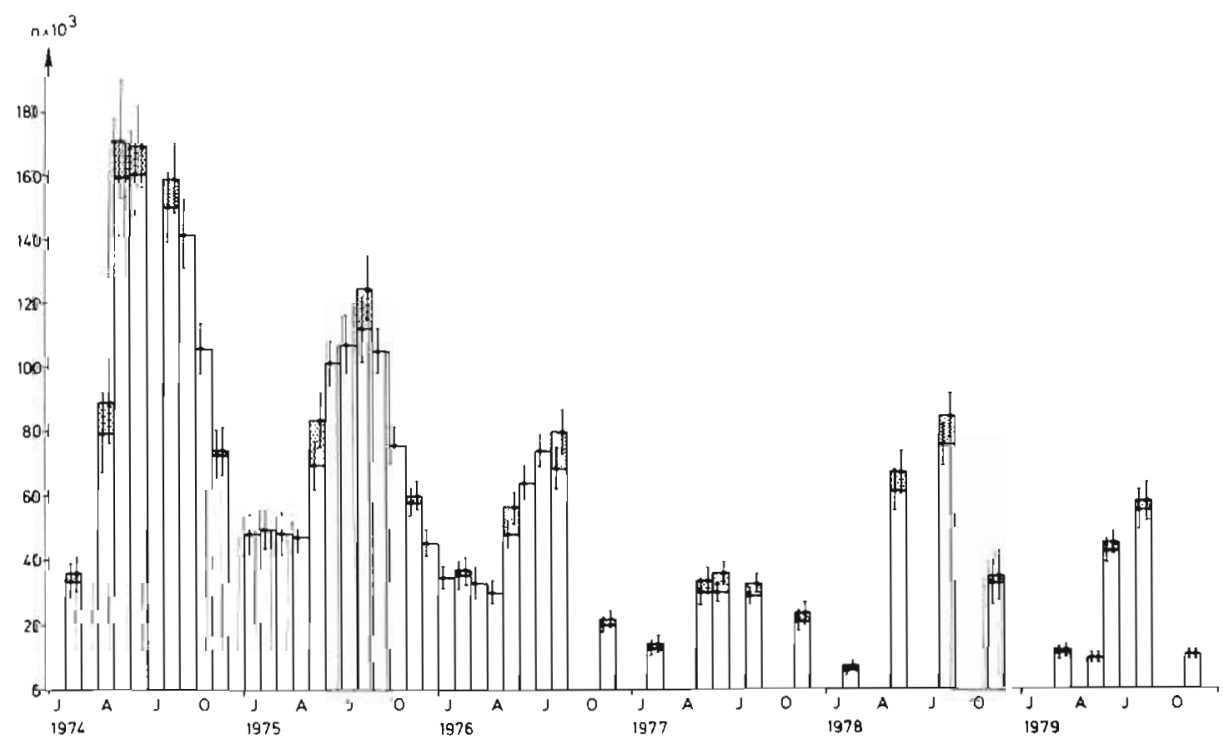

Fig. 3. Nassarius reticulatus. Average total number (with S. E.) in Kvarnbukten Bay (<1 m depth; 1974-1979). White columns: strata A, B, C plus D 1; stippled column: addition of D 2, E and F 
Table 3. Nassarius reticulatus. Size frequency distribution in percent on different substrates in Kvarnbukten Bay

\begin{tabular}{|c|c|c|c|c|c|c|}
\hline $\begin{array}{l}\text { Length } \\
(\mathrm{mm})\end{array}$ & $\begin{array}{l}\text { A1 } \\
\text { sand }\end{array}$ & $\begin{array}{c}\text { A2 } \\
\text { sand }+ \\
\text { carrion }\end{array}$ & $\begin{array}{c}\text { Overrepr. } \\
\text { inds } \mathrm{m}^{-2} \\
\text { A2/A1 }\end{array}$ & $\begin{array}{l}\text { A4 } \\
\text { sand }\end{array}$ & $\begin{array}{c}\mathrm{C} \\
\text { sand }+ \\
\text { detr. }\end{array}$ & $\begin{array}{c}\text { Overrepr } \\
\text { inds } \mathrm{m}^{-2} \\
\mathrm{C} / \mathrm{A4}\end{array}$ \\
\hline$\leqslant 10$ & 0.43 & 0 & - & 0.05 & 0.46 & $\approx 15 \times$ \\
\hline $11-14$ & 4.24 & 0.35 & $\approx 2 \times$ & 0.74 & 5.26 & $\approx 9 \times$ \\
\hline $15-18$ & 17.69 & 7.32 & $\approx 3 x$ & 7.46 & 19.15 & $\approx 5 x$ \\
\hline $19-22$ & 57.95 & 58.93 & $\approx 4 \times$ & 55.44 & 47.95 & $=3 \times$ \\
\hline $23-26$ & 19.34 & 32.39 & $\approx 5 \times$ & 35.18 & 24.76 & $\approx 4 \times$ \\
\hline$\geqslant 27$ & 0.43 & 0.28 & - & 1.18 & 0.86 & $\approx 1 \times$ \\
\hline
\end{tabular}

tively. The larger snails were particularly attracted to the dead and dying cockles in Stratum A 2 where the average snail was larger than in the surrounding $A$, without carrion (Table 3 ). These results indicate a shift in food preference from detritus among small snails to carrion among larger snails.

\section{Size Frequency Distribution in Different Areas}

The size frequency distribution of the snail population in the investigation area was very different from those of populations inhabiting deeper areas outside Kvarnbukten Bay (1-5 m) and in Lysekil harbour $(2-5 \mathrm{~m})$ (Fig. 4). Small snails ( $\leqslant 15 \mathrm{~mm}, \leqslant 3$ years) were very rare in Kvarnbukten Bay but occurred in some years just outside the bay and nearly every year in the harbour. Also in two other bays in the vicinity there was a higher proportion of small snails (35\% $\leqslant 15 \mathrm{~mm}$ ) in the summer of 1977 than in Kvarnbukten Bay, (16\%) at the same depth (Magnhagen, unpublished).

\section{Growth and Age}

The growth of Nassarius reticulatus can be divided into two steps. First, length increment took place only when water temperature exceeded $14{ }^{\circ} \mathrm{C}$, i. e. from early June to late August. The new part of the shell was very thin. Second, the new part of the shell thickened during autumn and winter. By locating the previous year ring and measuring the thickness of the outer lip the growth of the previous summer could be estimated. The first three year classes were discrete, their average size being ca. 5.5, 11 and $16.5 \mathrm{~mm}$, respectively. From the fourth year the growth rate decreased abruptly and became irregular. At the beginning of their fourth year the snails also normally became sexually mature. Most of the snails that were larger than $20 \mathrm{~mm}(70-80 \%)$ did not grow at all in some years (Fig. 5). The zero growth of many of the larger snails also prevented exact age determination on basis of the year rings. Large snails (25-33 mm) usually had 10-15 year rings, and thus the

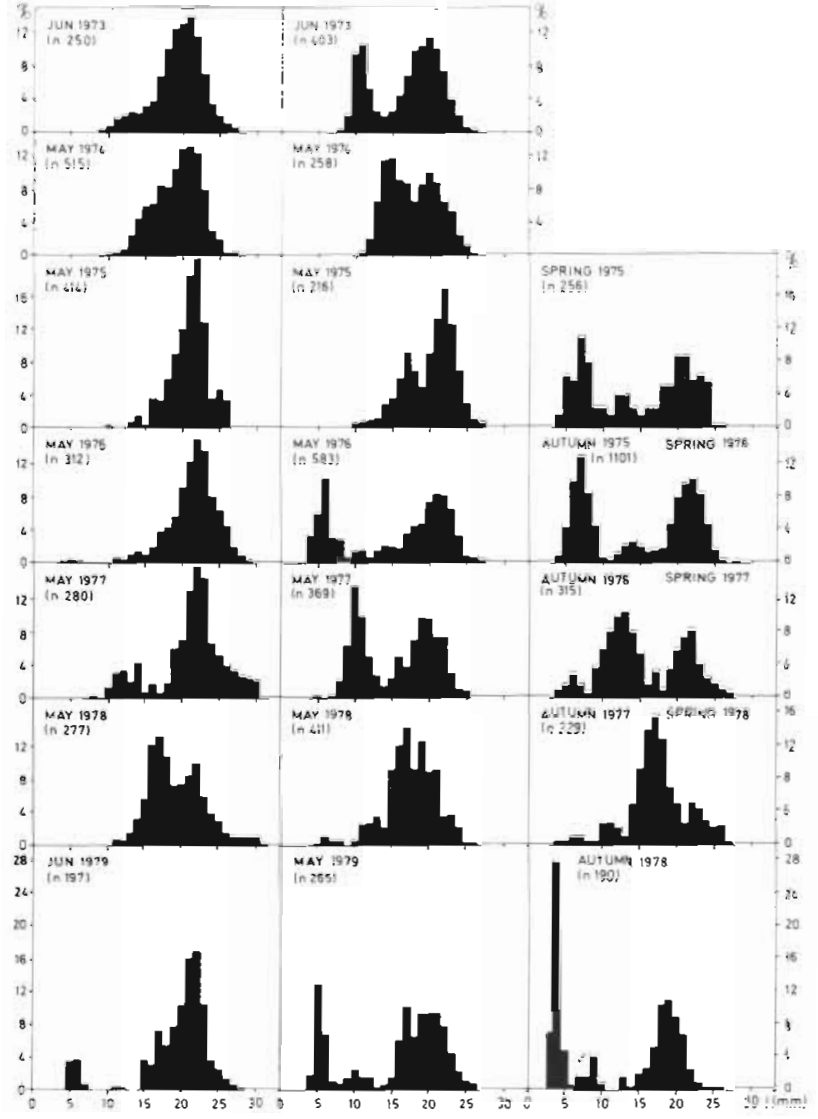

Fig. 4. Nassarius reticulatus. Size-frequency distribution in different areas of Gullmar Fjord. Left column: Kvarnbukten Bay, depth 0-1 m. Middle column: Kvarnbukten Bay, depth 1-3 m. Right column: Fishing harbour, Lysekil, depth 2-5 m

maximum age attained in the present population was at least 15 years. The maximum length found was $33 \mathrm{~mm}$. Very few snails reached the maximum age and a couple of years after the immigration the total number of snails had decreased considerably. The cumulative growth calculated on the growth of the different size classes is shown in Figure 6 as quartile values. In contrast to small snails whose growth was retarded due to the marking, snails larger than $15 \mathrm{~mm}$ grew at the same rate as unmarked ones. About $40 \%$ of the marked snails were recaptured at least once and many were recaptured several times. This indicates a low rate of emigration from the study area. One snail, $26 \mathrm{~mm}$ when marked, had not grown at all when recaptured 5 years later. This further demonstrates that some snails may attain an extremely high age. In the Lysekil harbour snails normally grew faster than in Kvarnbukten Bay, achieving average length values of $6.5,13$ and $18 \mathrm{~mm}$ after 1,2 and 3 years, respectively. The bottom substrate in the harbour was extremely rich in organic material, partly due to untreated sewage effluents from the town of Lysekil into the harbour. 


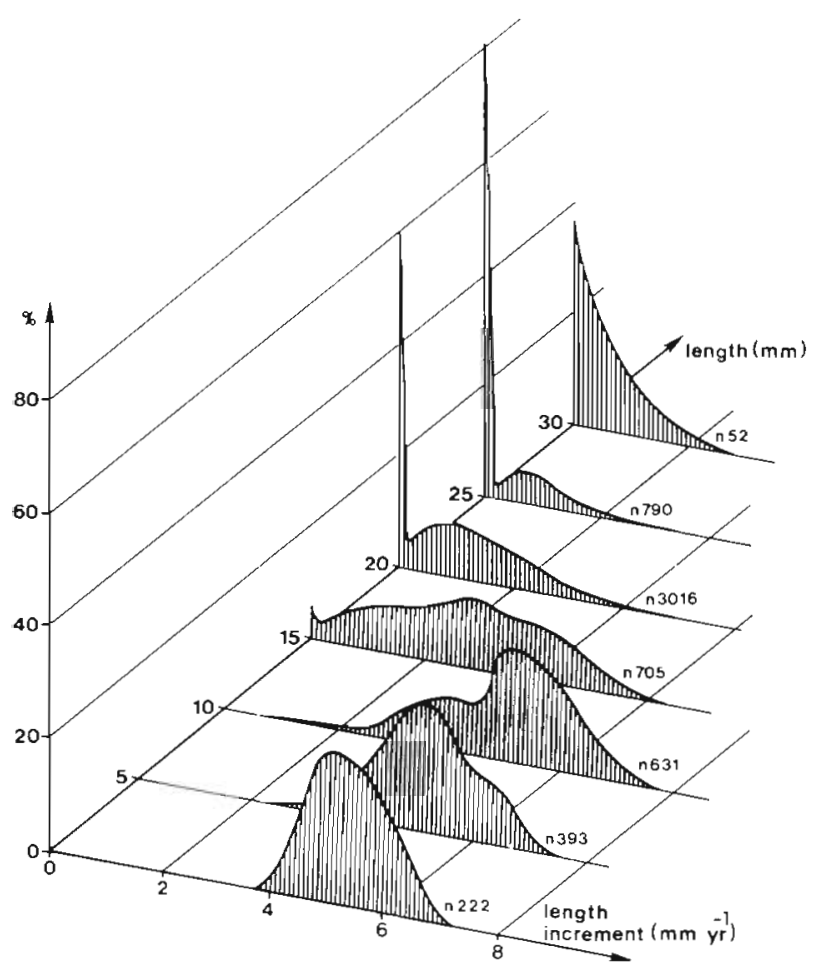

Fig. 5. Nassarius reticulatus. Average length increment at different sizes in Kvambukten Bay

\section{Recruitment and Mortality}

Comparing abundance and size-frequency distribution values from the autumn of one year with the values from the next spring allowed estimates of recruitment and mortality to be made, since the population fluctuations in the study area proper and the adjacent area were known to be parallel (Fig. 7). During the summer the population in Kvarnbukten Bay was stable (Table 2, Fig. 3), and thus mortality was

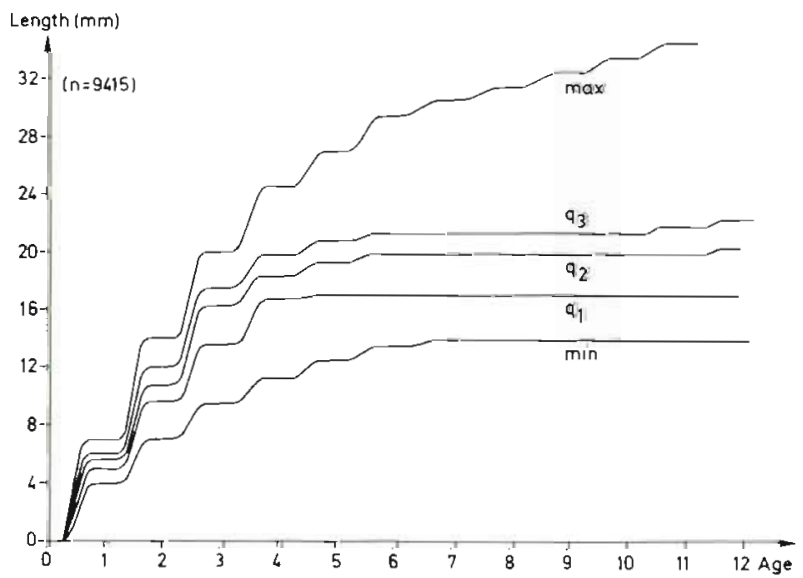

Fig. 6. Nassarius reticulatus. Growth and age in Kvarnbukten Bay. Quartile, maximun and minimum values (1975-1978)

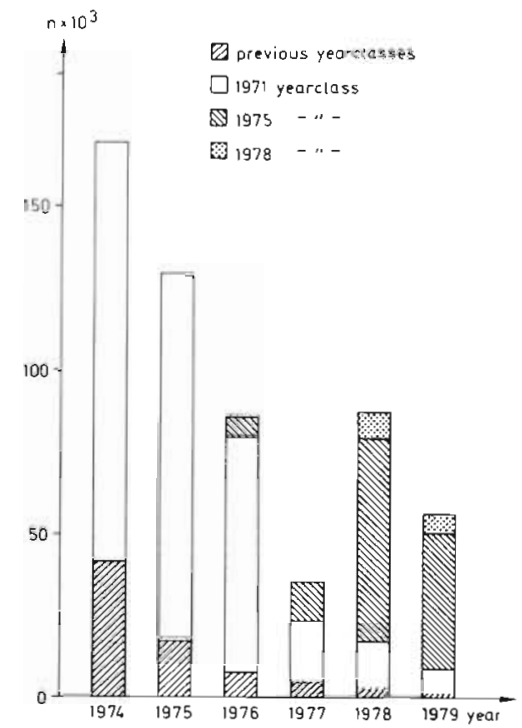

Fig. 7. Nassarius reticulatus. Composition of population with respect to year classes in Kvarmbukten Bay (1974-1979)

confined to the winter. Anaiyses of fish stomachs showed that the fish present did not eat snails. On one occasion in Gothenburg several snails were found in the stomach of an eider Somateria mollissima (J. Hendelberg, personal communication) but only a few eiders winter in this area.

Only three times during the 5 years from 1974 to 1979 was there any substantial recruitment of the population of Nassarius reticulatus in Kvarnbukten Bay. These recruitments consisted of the yearclasses of 1971, 1975 and 1978, respectively, and took place three years after the settling of the corresponding larvae in deeper water north of the study area (Fig. 4). The snails taking part in these recruitments had recently become sexually mature. Obviously, the snails' immigration into the shallower area was related to their spawning since they returned every year thereafter. In 1978, for the first time during this study, there was a minor settling of larvae even within the bay (Stratum C), which forecast another recruitment in 1981 of sexually mature snails.

Settling normally seemed to be confined to areas with higher content of organic matter in the substrate than the surroundings. The only stratum in Kvarnbukten Bay where snails settled was $C$ and even there settling was rare. In adjacent detritus-rich bays and in Lysekil harbour, settling was much more common. This indicates that the metamorphosis of Nassarius reticulatus larvae depends on the substrate and that detritus is the main food during their first three years of life. The larger snails gathered round dead and dying fishes, crabs and bivalves stranded on the beach. The declining population of Cardium edule in Kvambukten Bay, Stratum A 2 (Evans, 1977) could theoretically 


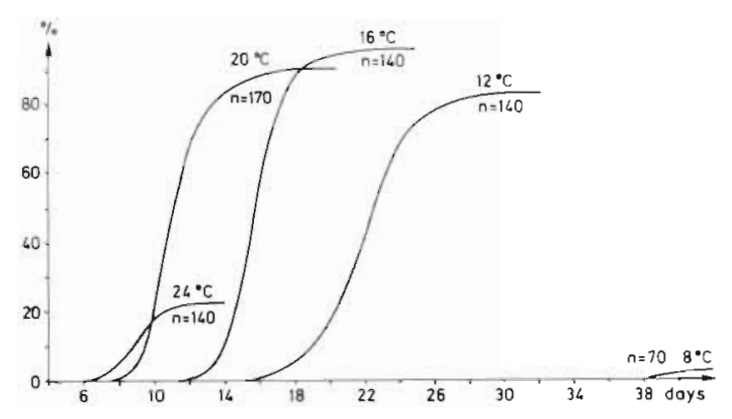

Fig. 8. Nassarius reticulatus. Time to hatching and hatching frequency of larvae at different temperatures under laboratory conditions. No larvae hatched at $4^{\circ}$ and $28^{\circ} \mathrm{C}$

feed about 100000 snails in 1975 , but the snails had numerous competitors for that particular carrion (Eriksson et al., 1975b).

\section{Fecundity and Larval Development}

The sex ratio for nonparasitized snails during spring when the snails are sexually active was ca. $52 \%$ males : $48 \%$ females. Among trematode-infected snails the proportion of males increased with size up to $70 \%$ ( $\geqslant 25 \mathrm{~mm}$ ) (cf. Tallmark and Norrgren, 1976).

The average number of egg capsules per female in the laboratory was 33.5 (range $8-66, \mathrm{n}=35$ ) at $16^{\circ} \mathrm{C}$. At $12{ }^{\circ} \mathrm{C}$, the average number was 23 and the egg laying period was prolonged from 15 to $25 \mathrm{~d}$; many of the egg capsules were empty, probably because the snails were not fed during this period. At $10^{\circ} \mathrm{C}$, they did not spawn for $30 \mathrm{~d}$. The average number of eggs per capsule in the field was 209 (range 126-322, $\mathrm{n}=60$ ).

The time from egg laying to hatching was positively correlated with temperature but hatching frequency decreased with both high and low temperature (Fig. 8). The optimum temperature was about $16^{\circ} \mathrm{C}$. The time from hatching to settling was also temperature dependent. At $20^{\circ} \mathrm{C}$, it took $25 \mathrm{~d}(\mathrm{n}=15)$; at $16{ }^{\circ} \mathrm{C}, 32 \mathrm{~d}$ $(\mathrm{n}=11)$.

\section{Survival and Growth in Laboratory Tests}

Laboratory tests on sterile sand showed that about $65 \%$ of the snails could survive 5 months staryation (Table 4). Adding organic matter to the substrate allowed a higher proportion (78\%) to survive and especially this improved the survival among the smaller snails. Of snails regularly fed mussel flesh about $95 \%$ survived. Growth of unfed snails was zero, except for the smallest size class on sand with detritus; here growth rate was half that of the normal rate.
Table 4. Nassarius reticulatus. Percentage survival in relation to available food in laboratory test during April-October 1975 $(n=417)$

\begin{tabular}{|ccccc|}
\hline $\begin{array}{c}\text { Length } \\
(\mathrm{mm})\end{array}$ & Sand & $\begin{array}{c}\text { Sand }+ \\
\text { detr. }\end{array}$ & $\begin{array}{c}\text { Sand }+ \\
\text { carrion }\end{array}$ & $\begin{array}{c}\text { Sand }+ \\
\text { detr. }+ \\
\text { carrion }\end{array}$ \\
\hline $10-14$ & 35.5 & 75.0 & 100 & 100 \\
$15-18$ & 80.6 & 80.0 & 100 & 96.7 \\
$19-25$ & 73.8 & 78.6 & 88.1 & 88.1 \\
Total & 64.4 & 77.9 & 95.3 & 94.2 \\
\hline
\end{tabular}

Snails fed mussel flesh grew at the same rate as those in Kvarnbukten Bay. Larger snails grew at a more even rate than those in the field. The laboratory test showed that the snails could survive by eating detritus, but that they needed carrion to grow, and their fecundity also depended on access to carrion. The fecundity of mussel-fed snails was about $50 \%$ higher than that of unfed ones; the former produced egg capsules for over 2 months compared with only 1 month in the field.

\section{Temperature and Activity}

Many activities of Nassarius reticulatus were clearly affected by temperature. Direct observations of the snails in the field disclosed the date for the start of locomotory activity, inshore migration, spawning, growth, offshore migration and quiescence in different years. These dates varied from year to year but the different activities commenced at the same water temperatures. Figure 9 summarizes the annual events in the life of the snails. It is based on laboratory tests examining the influence of temperature on initiation, conclusion and duration of various activities; on field observations; and on results obtained in the regular sampling program.

The threshold temperatures could be narrowly defined. For instance, when snails taken to the laboratory before spawning were held at $10^{\circ} \mathrm{C}$ they did not spawn for $30 \mathrm{~d}$, but at $12^{\circ} \mathrm{C}$ they started copulating within $2 \mathrm{~d}$ and produced egg capsules after another $3 \mathrm{~d}$.

Besides influencing their activity, temperature had a direct effect on the survival of the snails. Temperatures below freezing point killed Nassarius reticulatus in a few days (Eriksson and Tallmark, 1974; Eriksson et al., 1975a). Trematode-infected snails were particularly often killed by low temperatures, as they remained in shallow water, where low temperatures are frequent in the winter (Tallmark and Norrgren, 1976). 


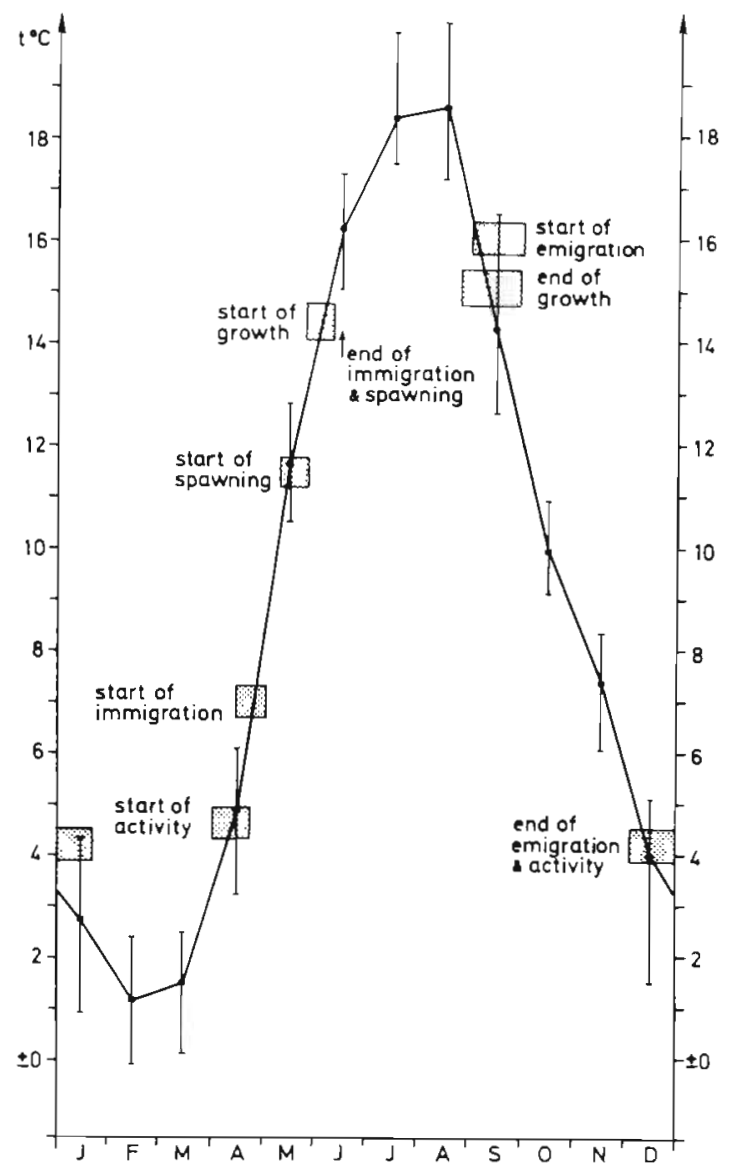

Fig. 9. Nassarius reticulatus. Annual activity schedule as well as monthly mean values and range of temperature (1974-1978). Stippled areas: range of temperature and of dates for start and end of different activities in different years

\section{DISCUSSION}

\section{Reproduction and Larval Development}

At the age of $3 \frac{1 / 2}{2}$ years Nassarius reticulatus normally became sexually mature. The inshore migration in spring with ensuing congregation within certain restricted areas in Kvarnbukten Bay may, as one of its selective advantages, facilitate the finding of a partner. In Isefjord, Denmark, spawning was observed from April to August (Rasmussen, 1973). At Hunterstone Generating Station in Scotland spawning took place in January when the maximum temperature in the sand near the warm-water outlet was $12^{\circ}-14^{\circ} \mathrm{C}$. Six $\mathrm{km}$ away spawning started 3 months later at a sand temperature of $8^{\circ}-9^{\circ} \mathrm{C}$ (Bamett, 1972). Gametogenesis is completed in autumn, and the abrupt increase in surface-water temperature in May appeared to release spawning in Kvarnbukten Bay at about $11^{\circ} \mathrm{C}$, whereas snails remaining in deeper water $(10 \mathrm{~m})$ spawned 3-4 weeks later. Thus, the onset of spawning is clearly influenced by water temperature.

The number of eggs per capsule in our study area was in accordance with findings reported from Denmark and Scotland (Thorson, 1946; Barnett, 1972). The length of the period during which planktonic larvae were found in the Oresund was probably due to different spawning times at various depths (Thorson, 1946). Larvae were exclusively found in the uppermost $10 \mathrm{~m}$ in the Plymouth area (Fretter and Shale, 1973). Metamorphosing larvae are ca. $0.8 \mathrm{~mm}$ (Lebour, 1931); in September they had grown to about $5-6 \mathrm{~mm}$ in Gullmar Fjord. The 0-group of 1978 in Lysekil harbour (Fig. 4) probably settled later than normally as their mean length was only about half that of the previous years.

\section{Metamorphosis and Recruitment}

In variable environments like the littoral zone, populations vary greatly from year to year and the numerical changes are asynchronous in adjacent populations (McIntyre, 1970; Spight, 1974; Lewis, 1977). The very uneven size-frequency distribution of bivalves in Kvarnbukten Bay is probably due to the same reason (Evans and Tallmark, 1976, 1977; Evans, 1977). Under laboratory conditions the planktonic phase from hatching to settling was found to require from 5 weeks (this study) to 9 weeks (Lebour, 1931).

Among prosobranch gastropods closely related to Nassarius some have planktonic, others direct development. Whether planktonic or not, $90-99 \%$ of the snails die in their first year of life; the survivors, however, may live up to 20 years (Spight et al., 1974; Spight, 1975).

Nassarius obsoletus larvae metamorphose in response to certain sediment properties. Since this species is primarily a deposit feeder, the selection of a favourable substrate with a high organic content has considerable adaptive values (Scheltema, 1961). $N$. reticulatus is also mainly a deposit feeder during its first years of life, and its metamorphosis is probably induced by a favourable substrate. The smaller size classes clearly preferred strata richer in detritus than adjacent ones (Table 3). Given a choice between sand with and without detritus in the laboratory the snails gathered in the former (Eriksson et al., 1975a). The poor survival and growth of snails offered detritus in the laboratory were probably due to the low organic content in the sand $(0.5 \%$ dry weight) compared with $3-15 \%$ in the areas where larvae settled in the field. Thus the predominantly detritus-poor sand in Kvarnbukten Bay appears to be suboptimal for settling of larvae and for the feeding of small snails. 


\section{Change of Diet}

When the snails migrate into shallow areas for the first time they change their diet. According to Rasmussen (1973), Nassarius reticulatus is predominantly a predator, but there was no support for that opinion in this study. Carrion and partly detritus seem to be the food resources for larger individuals. Stranded dead and dying animals tend to accumulate in shallow water. Such carrion can be quickly located (chemoreception) by many gastropods (Kohn, 1961). Even extremely low concentrations of a certain glycoprotein from oyster fluid $\left(10^{-10}\right.$ molar) induced a $50 \%$ positive response in $N$. obsoletus (Gurrin and Carr, 1971). Although their locomotory speed is low (ca. $12 \mathrm{~cm} \mathrm{~min}^{-1}$ ) these snails tend to outnumber all other scavenging species on carrion (Eriksson et al., 1975b) - even though there may be much denser local populations of these other species (Evans and Tallmark, 1979).

\section{Growth and Age}

The growth and particularly the age of many gastropods are difficult to determine. While the first 3 year classes can be easily separated by size, the decrease in growth rate from this age onwards probably depends on a strategic shift in energy allocation from growth to reproduction. When Nassarius obsoletus becomes sexually mature after the second year, its growth rate decreases abruptly (Scheltema, 1964).

Since growth is restricted to the period when water temperature exceeds ca. $14{ }^{\circ} \mathrm{C}$, it is selectively advantageous to migrate to shallow and thus warmer waters in the summer. The great effect of temperature on shell growth was also seen at Hunterstone, Scotland (Barnett, 1972), where the heated effluent accelerated growth rate which in turn led to shells much thinner than usual. Furthermore, there is presumably an important selective advantage of fast growth to escape predation. Trematode parasites also affect growth. Large infected snails ( $\geqslant 23 \mathrm{~mm}$ ) grew faster than uninfested ones (Tallmark and Helgesen, unpublished.) Whether this enhanced growth is confined to the shell or involves the whole animal is a matter of controversy (Cheng, 1971).

\section{Mortality}

In his review on the reproductive and larval ecology of marine bottom invertebrates Thorson (1950), listed food and temperature conditions, failure to find the right substrate, transport by currents, and predation as important sources of loss during the pelagic phase. We found egg capsules of Nassarius reticulatus in stomachs of the fish Ctenolabrus rupestris, but to a rather minor extent.

From the age of $3^{1 / 2}$ years and onwards the snails seem to have few predators. They are nocturnal and remain buried during daytime; this prevents or reduces predation (Eriksson and Tallmark, 1974; Eriksson et al., 1975b). Normally we found them to respond to olfactory stimuli also during the day, but when satiated they may refuse to respond to repeated stimulation for about $48 \mathrm{~h}$ (Crisp, 1978). Nassarius obsoletus shows a persistent tidal rhythm (Stephens et al., 1953) with maximum activity at high tide. Many species from tidal areas possess circa-tidal rhythrus with underlying circadian rhythms (cf. Palmer, 1973); restriction of locomotory activities to periods of high tide and darkness will probably reduce predation pressure because turbulence and darkness obscure prey animals from their predators.

Migration in autumn to deeper water is probably an adaptation to avoid the double risk of drying out at low water levels and of being caught in ground ice in shallow bays during cold winters. The same migration pattern as in Nassarius reticulatus is found in $N$. obsoletus (Batchelder, 1915; Sinderman, 1960). A certain proportion of the total population of snails in Kvarnbukten Bay were found to stay in deeper water all year round (Fig. 2). They thus avoid trematode infection which affected a rather high proportion of snails migrating into shallow water (Tallmark and Norrgren, 1976). Parasitized snails did not participate in the migrations, and most of them congregated in a slight depression in the bay (Stratum C). Infected snails exhibit a reduced condition and are more vulnerable to temperature stress; therefore, a higher percentage die in winter, compared with non-parasitized conspecifics (Tallmark and Norrgren, 1976). Moreover, infected snails become sterile. To avoid parasitation is thus of primary importance.

\section{CONCLUSIONS}

Nassarius reticulatus possesses many adaptations to cope with the strongly varying physical factors in the littoral environment. Different food requirements in different life-cycle stages have led to a partial separation of differently-sized individuals into different areas, and this may be a factor alleviating interspecific competition. Among the biotic factors, predation on young stages and parasitism in the older stages appear to be of great importance. Interestingly, the advantages of inshore migration (temperature, food acquisition) in the present population seem to balance neatly 
with the disadvantages (above all, parasitism); dimorphism in migratory habits can probably be viewed as adaptation to this situation.

Acknowledgements. I wish to thank Drs Svante Eriksson and Sverker Evans for collaboration, encouragement and stimulating discussions throughout the study. I also thank Professor Staffan Ulfstrand, and Drs Jan Löfberg, Göran Gezelius and Gunnar Bergh for helpful suggestions and criticism. Financial support for the investigation was obtained from the Swedish Natural Science Research Council (NFR 2196-102) and from the Royal Swedish Academy of Science.

\section{LITERATURE CITED}

Ankel, W. E. (1929). Über die Bildung der Eikapsel bei NassaArten. Zool. Anz. (Suppl.) 4: 219-230

Barnett, P. R. O. (1972) Effects of warm water effluents from power stations on marine life. Proc. R. Soc. Lond. B. Biol Sci. 180: 497-509

Batchelder, C. H. (1915). Migration of llyanassa obsoleta, Littorina littorea and Littorina rudis. Nautilus 29: 43-46

Carr, W. E. S. (1967a). Chemoreception in the mud snail Nassarius obsoletus. I. Properties of stimulatory substances extracted from shrimp. Biol. Bull. mar. biol. Lab., Woods Hole 133: 90-105

Carr, W. E. S. (1967b). Chemoreception in the mud snail Nassarius obsoletus. II. Identification of stimulatory substances. Biol. Bull. mar. biol. Lab., Woods Hole 133: 106-127

Cheng. T. C. (1971). Enhanced growth as a manifestation of parasitism and shell deposition in parasitized molluscs. In: Cheng, T. C. (ed.) Aspects of the biology of symbiosis. University Park Press, London, pp. 103-137

Copeland, M. (1918). The olfactory reactions and organs of the marine snails Alectrion obsoleta (Say) and Buscyon canaliculatum (Linn.). J. exp. Zool. 25: 177-227

Crisp, M. (1969). Studies on the behavior of Nassarius obsoletus (Say) (Mollusca, Gastropoda). Biol. Bull. mar. biol. Lab., Woods Hole 136: 355-373

Crisp, M. (1971). Structure and abundance of receptors of the unspecialized external epithelium of Nassarius reticulatus (Gastropoda, Prosobranchia). J. mar. biol. Ass. U. K. 51: $865-890$

Crisp, M. (1978). Effects of feeding on the behaviour of Nassarius-species (Gastropoda, Prosobranchia). J. mar. biol. Ass. U. K. 58: 659-669

Crisp, M., Davenport, J., Shumway, S. E. (1978). Effects of feeding and of chemical stimulation on the oxygen uptake of Nassarius reticulatus (Gastropoda, Prosobranchia). J. mar. biol. Ass. U. K. 58: 387-399

Dimon, A. C. (1905). The mud snail: Nassa obsoleta. Cold Spring Harbor Monogr. 5: 1-48

Dippolito, A., Sienko, J., Smith, B. S. (1975). Relationship between mud snail and periwinkle. Proc. malacol. Soc. Lond. 41: 529-532

Eriksson, S., Tallmark, B. (1974). The influence of environmental factors on the diurnal rhythm of the prosobranch gastropod Nassarius reticulatus (L.) from a non-tidal area. Zoon 2: 135-142

Eriksson, S., Evans, S., Tallmark, B. (1975a). On the coexistence of scavengers on shallow, sandy bottoms in Gullmar Fjord (Sweden): Adaptation to substratum, temperature and salinity. Zoon 3: 65-70

Eriksson, S., Evans, S., Tallmark, B. (1975b). On the coexist- ence of scavengers on shallow, sandy bottoms in Gullmar Fjord (Sweden): Activity patterns and feeding ability. Zoon 3: 121-124

Evans, S. (1977). Growth, production and biomass release of a non-stable population of Cardium edule (L.) (Bivalvia). Zoon 5: 133-141

Evans, S., Tallmark, B. (1975). Abiotic factors on a shallow, sandy bottom in Gullmar Fjord (Sweden): Temperature, salinity, water level, currents, grain size and organic matter. Zoon 3: 61-64

Evans, S., Tallmark, B. (1976). Distribution and size frequency of bivalve molluscs on a shallow, sandy bottom in Gullmar Fjord (Sweden). Zoon 4: 47-52

Evans, S., Tallmark, B. (1977). Growth and biomass of bivalve molluscs on a shallow, sandy bottom in Gullmar Fjord (Sweden). Zoon 5: 33-38

Evans, S., Tallmark, B. (1979). A modified drop-net method for sampling mobile epifauna on marine, shallow, sandy bottoms and its application in a Swedish Fjord. Holarct. Ecol. 2: 58-64

Fretter, V., Shale, D. (1973). Seasonal changes in population density and vertical distribution of prosobranch veligers in offshore plankton at Plymouth. J. mar. biol. Ass. U. K. 53: 471-492

Gurrin, S., Carr., W. E. (1971). Chemoreception in Nassarius obsoletus: The role of specific stimulatory proteins. Science, N. Y. 174: 293-295

Henschel, J. (1933). Untersuchungen über den chemischen Sinn von Nassa reticulata. Wiss. Meeresunters., Abt. Kiel 21: $133-158$

Jenner, C. E. (1956). The timing of reproductive cessation in geographically separated populations of Nassarius obsoletus. Biol. Bull. mar. biol. Lab., Woods Hole 111: 292

Jenner, C. E. (1958). An attempted analysis of schooling behavior in the marine snail Nassarius obsoletus. Biol. Bull. mar. biol. Lab., Woods Hole 115: 337

Jenner, C. E. (1959). Aggregation and schooling in the marine snail Nassarius obsoletus. Biol. Bull. mar. biol. Lab., Woods Hole 117: 397

Kohn, A. J. (1961). Chemoreception in gastropod molluscs. Am. Zool. 1: 291-308

Lebour, M. V. (1931). The larval stages of Nassarius reticulatus and Nassarius incrassatus. J. mar. biol. Ass. U. K. 17: 797-818

Lewis, J. R. (1977). The role of physical and biological factors in the distribution and stability of rocky shore communities. In: Keegan, B. F., Ceidigh, P. O., Boaden, P. J. S. (eds) Biology of benthic organisms. Pergamon Press, Oxford, pp. $417-424$

McIntyre, A. D. (1970). The range of biomass in intertidal sand with special reference to the bivalve Tellina tenuis. J. mar. biol. Ass. U. K. 50: 561-575

Palmer, J. D. (1973). Tidal rhythms: The clock control of the rhythmic physiology of marine organisms. Biol. Rev. Camb. Philos. Soc 48: 377-418

Pilkington, M. C., Fretter, V. (1970). Some factors affecting the growth of prosobranch veligers. Helgoländer wiss. Meeresunters. 20: 576-593

Rasmussen, E. (1973). Systematics and ecology of the Isefjord marine fauna (Denmark). Ophelia 11: 1-507

Sastry, A. N. (1970). Effect of temperature on egg capsule deposition in the mud snail Nassarius obsoletus (Say). Veliger 13: 339-341

Scheltema, R. S. (1961). Metamorphosis of the veliger larvae of Nassarius obsoletus (Gastropoda) in response to bottom sediment. Biol. Bull. mar. biol. Lab., Woods Hole 120: 92-109 
Scheltema, R. S. (1964). Feeding habits and growth in the mud snail Nassarius obsoletus. Chesapeake Sci. 5: 161-166

Scheltema, R. S. (1965). The relationship of salinity to larval development in Nassarius obsoletus (Gastropoda). Biol. Bull. mar. biol. Lab., Woods Hole 129: 340-354

Scheltema, R. S. (1967). The relationship of temperature to the larval development of Nassarius obsoletus (Gastropoda). Biol. Bull. mar. biol. Lab., Woods Hole 132: 253-265

Sinderman, C. J. (1960). Ecological studies of marine dermatis-producing schistosome larvae in northern New England. Ecology 41: 678-684

Snedecor, G. W., Cochran, W. G. (1967). Statistical methods, Iowa State University Press, Ames

Spight, T. M. (1974). Sizes of populations of a marine snail Ecology 55: 712-729
Spight, T M. (1975). On a snail's chances of becoming one year old. Oikos 26: 9-14

Spight, T. M., Birkeland, C., Lyons, A. (1974). Life histories of large and small murexes (Prosobranchia, Muricidae). Mar. Biol. 24: 229-242

Stephens, G. C., Sandeen, M. I., Webb, H. M. (1953). A persistent tidal rhythm of activity in the mud snail Nassa obsoleta. Anat. Rec. 117: 635

Tallmark, B., Norrgren, G. (1976). The influence of parasitic trematodes on the ecology of Nassarius reticulatus (L.) in Gullmar Fjord (Sweden). Zoon 4: 149-154

Thorson, G. (1946). Reproduction and larval development of Danish marine bottom evertebrates. Medd. Dan. Fisk: Havunders. 4: 1-523

Thorson, G. (1950). Reproductive and larval ecology of marine bottom invertebrates. Biol. Rev. Camb. Philos. Soc. 25: $1-45$

This paper was submitted to the editor; it was accepted for printing on April 18, 1980 